\title{
Efficacy of Some Combined Conservative Methods in the Treatment of Carpal Tunnel Syndrome: A Randomized Controlled Clinical and Electrophysiological Trial
}

\author{
Karpal Tünel Sendromunun Tedavisinde Bazı Kombine Konservatif Yöntemlerin Etkinliği: \\ Randomize, Kontrollü, Klinik ve Elektrofizyolojik Bir Çalışma
}

\author{
Tomris DUYMAZ, ${ }^{1}$ Dilşad SİNDEL, ${ }^{2}$ Nur KESİKTAŞ, ${ }^{2}$ Lütfiye MÜSLÜMANOĞLU ${ }^{2}$ \\ ${ }^{1}$ Department of Physical Medicine and Rehabilitation, School of İstanbul University, İstanbul, Turkey \\ ${ }^{2}$ Department of Physical Medicine and Rehabilitation, Medical Faculty of İstanbul University, İstanbul, Turkey
}

\begin{abstract}
Objectives: In this study, we aimed to compare the efficacy of some conservative methods in combination with dexamethasone iontophoresis, ultrasound therapy or placebo iontophoresis (without dexamethasone) in the treatment of mild carpal tunnel syndrome (CTS). Patients and methods: Fifty-eight patients diagnosed with mild CTS confirmed by electromyography were included in the study. The subjects were divided randomly into three groups: (i) iontophoresis group-treated with dexamethasone iontophoresis $(n=20)$; (ii) ultrasound group-treated with ultrasound $(n=20)$, and (iii) placebo group-treated with placebo iontophoresis $(n=18)$. All patients received one of these treatments in 15 sessions for three months in combination with physiotherapeutic procedures, such as tendon/nerve gliding exercises, night splinting and activity modifications. Wrist range of motion, muscle test, the Visual Analog Scale (VAS), handgrip test, pinch meter measurement, sensory testing with monofilaments, two-point discrimination test, Phalen's, reverse Phalen's, Tinnel's and carpal compression test, the Health Assessment Questionnaire (HAQ), the Boston Questionnaire (BQ) and electrophysiological assessment were performed at baseline, at the end of therapies and at threemonths during follow-up. Statistical analysis was performed using SPSS software (version 10.0 for Windows).
\end{abstract}

Results: Statistically significant improvements in the clinical status of all groups were observed at the end of the study $(p \leq 0.05)$. Compared to ultrasound group and placebo group, more successful outcomes were seen in the iontophoresis group, resulting in statistically significant improvements in the pinch meter measurements, monofilament and two-point discrimination tests, and in $B Q$ scores at three months during follow-up $(p \leq 0.05)$. A statistically significant improvement was also recorded in the electrophysiological measurements in the iontophoresis group and ultrasound group $(p \leq 0.05)$.

Conclusion: Our study results suggest that dexamethasone iontophoresis administration combined with tendon gliding exercises, splint and activity modification is reliable and effective in the treatment of patients with mild CTS. However, further large-scale studies are required to confirm these findings.

Key words: Carpal tunnel syndrome; dexamethasone iontophoresis; exercise; splinting; ultrasound.

\begin{abstract}
Amaç: Bu çalışmada, hafif karpal tünel sendromu (KTS) tedavisinde bazı konservatif yöntemlerle birlikte uygulanan deksametazon iyontoforezi veya ultrason veya plasebo iyontoforezin (deksametazonsuz) etkinliği karşılaştırıldı.

Hastalar ve yöntemler: Elektromiyografi ile doğrulanmış hafif KTS tanılı 58 hasta çalışmaya dahil edildi. Hastalar rastgele üç gruba ayrıldı: (i) deksametazon iyontoforezi ile tedavi edilen iyontoforez grubu $(n=20)$; (ii) ultrason ile tedavi edilen grup $(n=20)$ ve (iii) plasebo iyontoforezi uygulananlar $(n=18)$. Bu tedavilerden biri, tüm hastalara üç aylık tendon ve sinir kaydırma egzersizleri, gece splinti ve aktivite modifikasyonları gibi fizyoterapi prosedürleri ile beraber 15 seans uygulandı. Tedavinin başında, tedavi sonunda ve tedavi bitiminden sonra takip sırasında 3. ayda el bileği eklem hareket açıklığı ve kas testleri, Görsel Analog Skalası (VAS), el sıkma testi, pinçmetre ölçümleri, monofilaman ile duyu testleri, iki nokta diskriminasyon testi, Phalen, ters Phalen, Tinel ve karpal kompresyon testleri, Sağlık Değerlendirme Anketi (HAQ), Boston Sorgulama Anketi (BQ) ve elektrofizyolojik ölçümler değerlendirildi. İstatistiksel analiz SPSS (versiyon 10.0, Windows) yazılımı kullanılarak yapıldı.
\end{abstract}

Bulgular: Çalışma sonunda tüm grupların klinik değerlendirmelerinde istatistiksel olarak anlamlı iyileşmeler görüldü $(p \leq 0.05)$. Ultrason ve plasebo grubu ile karşılaştırıldığında, iyontoforez grubunda daha başarılı sonuçlar alındı; KTS'li hastaların üç ay sonraki takiplerinde pinçmetre, monofilaman, iki nokta diskriminasyon testleri ve $B Q$ skorlarında istatistiksel anlamlı iyileşme gözlemlendi $(p \leq 0.05)$. İyontoforez ve ultrason grubunda yapılan elektrofizyolojik ölçümlerde de, istatistiksel olarak anlamlı iyileşmeler kaydedildi ( $\mathrm{p} \leq 0.05)$.

Sonuç: Bu çalışmanın sonuçları, hafif KTS'li hastaların deksametazon iyontoforezi, tendon kaydırma egzersizleri, splint ve aktivite modifikasyonu ile beraber tedavisinin güvenilir ve etkili olduğunu önermektedir. Ancak, bulgularımızı destekleyen daha geniş ölçekli başka çalışmalara da intiyaç vardır.

Anahtar sözcükler: Karpal tünel sendromu; deksametazon iyontoforezi; egzersiz; splintleme; ultrason.

\section{Received: August 25, 2011 Accepted: January 3, 2012}

Correspondence: Dilşad Sindel, M.D. İstanbul Üniversitesi İstanbul Tıp Fakültesi, Fiziksel Tıp ve Rehabilitasyon Anabilim Dalı, 34390 Çapa, İstanbul,

Turkey. Tel: +90 212 - 6351185 e-mail: sindel@istanbul.edu.tr

(02012 Turkish League Against Rheumatism. All rights reserved. 
Carpal tunnel syndrome (CTS) is the entrapment mononeuropathy most frequently encountered in clinical practice. It is caused by the compression of the median nerve at the wrist level. ${ }^{[1,2]}$ Several physical examination tests may be helpful in the diagnosis of CTS, but none of them are diagnostic on their own. The gold standard test is a nerve conduction study. ${ }^{[3]}$ Patients with mild and moderate CTS symptoms can be managed with conservative treatment. ${ }^{[4-10]}$ However, in severe cases, surgery may be required. ${ }^{[9]}$

Several treatment choices exist for CTS, and these can be broadly divided into surgical and conservative categories. The various conservative methods include hand bracing, wrist splinting, ultrasound, laser therapy, steroids, nonsteroidal anti-inflammatory drugs (NSAIDs), vitamin B6, local injections, workplace modifications, and yoga. ${ }^{[4-8,10]}$ Releasing operations have therapeutic effects, but complications and failure have been shown to occur in $3-19 \%$ of cases. ${ }^{[9,10]}$

A universally accepted therapy for CTS is not available yet. Some reviews exist regarding conservative methods; however, there are conflicting results regarding this issue among the various studies. Additionally, treatment involving combinations of surgical and conservative methods have not been studied well. ${ }^{[11-13]}$ Designing protocols for CTS which include conservative methods is needed.

Workplace modifications or job changes are very important in the treatment of CTS. ${ }^{[2]}$ However, patient education must be the first step in all treatment protocols.

Splinting of the wrist in the neutral position for nocturnal wear is the most effective non-aggressive treatment for CTS. It is advised for the resolution of clinical symptoms, especially for pain relief. There are many studies regarding splint application in neutral and extension positions. ${ }^{[14,15]}$ The median nerve gliding exercises that have been used in clinical trials for CTS were proposed by Totten and Hunter. With these exercises, joint movements alter the length of the nerve bed and induce gliding of the nerve relative to its surrounding structures. ${ }^{[16]}$

Iontophoresis is a procedure which leads to chemical modifications and the transferral of ions to the body using direct current. Dexamethasone administered by the iontophoresis technique has the effect of reducing tissue inflammation by inhibiting the biosynthesis of inflammatory substances. ${ }^{[17]}$ During the last decade, iontophoresis has especially gained popularity as a treatment modality for CTS. ${ }^{[4,18-20]}$
Ultrasound has been widely used in hand therapy to promote recovery after nerve and tendon injuries. ${ }^{[21]}$ Several intensities and frequencies have been used for CTS. ${ }^{[4,12,21-25]}$

Electrophysiological evaluation is important for both diagnosis (as a gold standard) and effective treatment. There are only a few studies which have been conducted with CTS patients at followup in which the effectiveness was demonstrated electrophysiologically. ${ }^{[24,26,27]}$

The aim of this study was to investigate clinically and electrophysiologically the effectiveness of conservative treatment protocols in the management of idiopathic CTS and to compare them.

\section{PATIENTS AND METHODS}

This study enrolled patients who had been clinically and electrophysiologically diagnosed as having CTS in the outpatient clinic of the Physical Medicine and Rehabilitation Department in İstanbul Faculty of Medicine, İstanbul University, İstanbul.

Fifty-eight CTS patients (55 females, 3 males; mean age 51.85 \pm 7.29 ) were included in the study. The sample size was estimated using the results from a previous study. ${ }^{[10]}$ The study protocol was approved by the university ethics committee, and written informed consent was obtained from all patients. This study was a prospective, randomized, blind clinical trial with a follow-up after three months. The persons' who performed the statistical analysis and electrophysiological assessment was blind to the therapy as were the patients who received dexamethasone iontophoresis or sham iontophoresis.

Before including a patient in the study, a detailed history was obtained, and the possibility of other diseases was eliminated by physical examination and electrophysiological measurements. Same physician (one of the author of study) checked all the patients, another author of the study performed all the electrophysiological measurements.

The study participants were volunteers, aged 25-70 years, who were unemployed at the time of study. The inclusion criteria were a diagnosis of idiopathic CTS based on provocation tests and electromyography (EMG) during the examination and complaints of numbness, tingling, weakness, and pain in the hands lasting for at least three months. Bland's scale was used to grade the CTS severity. ${ }^{[3]}$ 
Exclusion criteria were the following: the presence of symptoms for more than a year, acute findings, a history of steroid injections or physical therapy, systemic disease, a two-point discrimination distance of greater than $6 \mathrm{~mm}$, the presence of thenar atrophy, more proximal complex neuropathy, cervical discopathy, cervical Da Costa's syndrome, shoulder, elbow, wrist, or finger problems (frozen shoulder, epicondylitis, cubital tunnel syndrome, history of wrist fracture, trigger finger), the presence of a pacemaker, and other etiological causes leading to CTS, e.g. rheumatoid arthritis, gout, pregnancy, or previous CTS surgery.

The patients were randomly divided into three groups using computer-generated random numbers. After the examination of each patient, the physician sent the number in an envelope to the physiotherapist.

\section{Intervention}

The iontophoresis group (group I) consisted of twenty hands which received dexamethasone iontophoresis using a galvanic device (Medelsan Galvani-Faradi Stimulator 01.300502.16255.010 I.U. BIOMED and KL.MUH.BR, Turkey), the sham group (group S) was comprised of 18 hands that received sham iontophoresis, and the ultrasound group (group U) contained the remaining 20 hands which were treated with underwater ultrasound using an ultrasound device (Intelect 200 Sound, 1063C, 98/664, Turkey). Prior to treatment, the area was cleaned, and all metals were removed from the body. In iontophoresis therapy, dexamethasone sodium diphosphate $0.4 \%$ solution was poured on the activated carbon electrode pad of $25 \mathrm{~cm}^{2}$ placed over the carpal tunnel. Since the passive electrode was larger, it was placed proximally on the forearm. The administration was performed by applying a current of $2 \mathrm{~mA}$ for 20 minutes. In group $S$, water was used instead of the dexamethasone solution on the active electrode, and the treatment was performed using the same device, intensity, and duration.

With ultrasound therapy, the patient's arm was immersed up to the elbow in a basin of warm water, and the therapy was administered with horizontal and longitudinal movements of the palm on the palmar surface of the carpal tunnel and the third finger of the hand. Ultrasound treatment was applied for five minutes per session using direct current with an intensity of $0.8 \mathrm{~W} / \mathrm{cm}^{2}$. The three applications were performed by a physiotherapist once a day five times a week over a period of three weeks.
All patients received training in both written and oral form in order to perform tendon and nerve gliding exercises and were instructed to do three sets of 10 of these exercises every day. This was in addition to the previously mentioned therapies. Brochures describing the exercises were also dispensed. Ergonomic training for daily living activities was also given to all patients.

Neutral wrist splinting was also provided to the patients, who were instructed to wear the splint at night.

\section{Outcome measurements}

The visual analog scale (VAS) for pain evaluation, wrist flexion/extension range of motion measurements, muscle testing for the muscles in this region (using five points scale), a muscle test for abductor pollicis brevis (APB), an evaluation of handgrip strength, pinch meter measurements, and the Semmes-Weinstein monofilaments (SWM) examination for sense evaluation were performed for clinical assessment along with Phalen's, Reverse Phalen's, Tinel's and carpal compression tests. In addition, the Boston Questionnaire (BQ) and the Health Assessment Questionnaire (HAQ) were completed.

The BQ was used to assess symptom severity and functional status while the HAQ was used to evaluate disability. The Turkish versions were found to be viable. ${ }^{[28,29]}$

All electrodiagnostic tests were performed using an electroneuromyography device (Nihon Kohden Neuropack M1, Japan). Motor and sensory nerve conduction studies were performed in the median and ulnar nerves. The measurements of median nerve sensory distal latency, sensory amplitude, velocity of sensory nerve conduction, motor distal latency, motor amplitude, and velocity of motor nerve conduction were done using standard techniques. Compound muscle action potentials of the APB muscle induced by supramaximal electric stimulation of the median nerve at the wrist $8 \mathrm{~cm}$ to the recording electrode were recorded. Antidromic sensory latency and sensory nerve conduction studies were done from the second digit to the wrist at a distance of $14 \mathrm{~cm} \cdot{ }^{[26]}$

The clinical and electrodiagnostic evaluations were repeated three times: before and after therapy and at the three-month follow-up. 


\section{Statistical analysis}

In the present study, statistical analyses were made using Statistical Package for Social Sciences (SPSS Inc., Chicago, Illinois, USA) version 10.0 for Windows. Although most of our measurements were parametric, those which were non-normally distributed were analyzed using non-parametric methods. One-way analysis of variance (ANOVA) was applied to compare parametric values. To evaluate the non-parametric measurements, the Wilcoxon test and McNemar's test were used for within-group comparison, and the Kruskal-Wallis test was used for comparison between groups. A Bonferroni correction was applied to adjust the level of significance due to the presence of multiple comparisons. Statistical significance was set at $\mathrm{p} \leq 0.05$ and considered to be two-sided.

\section{RESULTS}

There was no statistically significant difference in mean age, dominant hand, and involved hand between the study groups. The female/male ratio was 18.3:1. Demographic characteristics are presented in Table 1.

No difference was found between the groups regarding measurements of flexion/extension range of motion ( $\mathrm{p}>0.05)$.

There was no difference between the groups in VAS scores during movement, at rest, or nighttime at the beginning of therapies. Statistically significant improvement in VAS scores during movement and at rest was seen in group I $(\mathrm{p}<0.001)$ and was still observed three months later during post-treatment $(\mathrm{p}<0.001)$ (Table 2). The change was significant even after a $\mathrm{p}$-value adjustment using the Bonferroni correction $(\mathrm{p}=0.05 /$ number of tests; $0.05 / 2=0.025)$.

No significant difference was found in handgrip and pinch meter measurements between the groups at baseline ( $\mathrm{p}>0.05)$. Statistically significant improvement was observed in pinch meter measurements in group I at the three-month post-treatment when compared to group $S$ and group $U(p<0.001)$.

It was found that the iontophoresis method was more efficient when the groups were compared in terms of strength of the APB muscle before and after treatment and at the three-month follow-up $(\mathrm{p}<0.001)$.

A statistically significant difference in the Tinel's test was detected before treatment and again three months later in group $\mathrm{U}$, with a more pronounced difference in group I $(p<0.001)$. When comparing the groups regarding flick sign, a statistically significant difference was seen in group I both after treatment and at the three-month follow-up $(\mathrm{p}<0.001)$.

Statistically significant differences in the Phalen's test were found between the groups both before and after treatment and at the three-month followup ( $\mathrm{p}<0.001, \mathrm{p}=0.01, \mathrm{p}=0.05$, respectively) with the significance being greater in group $\mathrm{U}(\mathrm{p}<0.001)$.

Statistically significant differences in the Reverse Phalen's test were also detected before treatment, immediately afterward, and during the follow-up three

\begin{tabular}{|c|c|c|c|c|c|c|c|}
\hline & \multicolumn{2}{|c|}{ Group I $(n=20)$} & \multicolumn{2}{|c|}{ Group S (n=18) } & \multicolumn{2}{|c|}{ Group U $(n=20)$} & \multirow[b]{2}{*}{$p$} \\
\hline & Mean \pm SD & $\%$ & Mean \pm SD & $\%$ & Mean \pm SD & $\%$ & \\
\hline Age (years) & $51.50 \pm 8.08$ & & $53.70 \pm 8.35$ & & $51.25 \pm 6.88$ & & 0.55 \\
\hline BMI $\left(\mathrm{kg} / \mathrm{m}^{2}\right)$ & $29.11 \pm 6.24$ & & $30.19 \pm 5.40$ & & $27.81 \pm 4.17$ & & 0.39 \\
\hline \multicolumn{8}{|l|}{ Gender } \\
\hline Female & & 90 & & 100 & & 95 & 0.38 \\
\hline Male & & 10 & & & & 5 & 0.38 \\
\hline APB muscle test & $4.2 \pm 0.69$ & & $4.11 \pm 0.47$ & & $4.2 \pm 0.69$ & & 0.80 \\
\hline Carpal compression test & $45.00 \pm 21.03$ & & $40.05 \pm 19.52$ & & $39.55 \pm 20.33$ & & 0.45 \\
\hline Handgrip strength & $46.56 \pm 19.47$ & & $47.44 \pm 10.81$ & & $50.63 \pm 16.22$ & & 0.80 \\
\hline Pinch strength & $12.75 \pm 3.57$ & & $12.64 \pm 2.56$ & & $13.53 \pm 3.91$ & & 0.67 \\
\hline Wrist flexion & $72.15 \pm 8.84$ & & $70.83 \pm 11.40$ & & $75.25 \pm 10.32$ & & 0.39 \\
\hline Wrist extension & $62.25 \pm 8.34$ & & $60.00 \pm 6.41$ & & $63.25 \pm 7.48$ & & 0.40 \\
\hline Two-point discrimination & $5.45 \pm 1.82$ & & $4.88 \pm 1.40$ & & $5.40 \pm 1.69$ & & 0.52 \\
\hline Semmes-Weinstein monofilament & $3.70 \pm 0.42$ & & $3.60 \pm 0.25$ & & $3.79 \pm 0.33$ & & 0.24 \\
\hline HAQ & $0.80 \pm 0.71$ & & $0.77 \pm 0.73$ & & $0.80 \pm 0.67$ & & 0.85 \\
\hline Boston symptom severity & $26.40 \pm 8.78$ & & $26.55 \pm 7.60$ & & $30.55 \pm 8.84$ & & 0.22 \\
\hline Boston functional capacity & $18.35 \pm 8.42$ & & $16.38 \pm 7.01$ & & $21.05 \pm 7.67$ & & 0.18 \\
\hline
\end{tabular}


Table 2. Comparison between the groups in terms of differences in VAS pain at movement, rest, and night

\begin{tabular}{|c|c|c|c|c|c|c|c|c|c|c|}
\hline & \multicolumn{3}{|c|}{ Group I } & \multicolumn{3}{|c|}{ Group S } & \multicolumn{3}{|c|}{ Group U } & \multirow[b]{2}{*}{$p$} \\
\hline & Mean \pm SD & Median & (min.-max.) & Mean \pm SD & Median & (min.-max.) & Mean \pm SD & Median & (min.-max.) & \\
\hline VAS movement 1 & $2.75 \pm 1.71$ & 3.00 & $(0.00-6.00)$ & $0.66 \pm 1.13$ & 0.00 & $(0.00-3.00)$ & $1.30 \pm 1.83$ & 0.00 & $(-1.00-5.00)$ & $\mathrm{p}<0.001^{\star}$ \\
\hline VAS movement 2 & $1.20 \pm 1.23$ & 1.00 & $(0.00-4.00)$ & $0.11 \pm 1.40$ & 0.00 & $(-3.00-3.00)$ & $0.85 \pm 1.66$ & 0.00 & $(-2.00-6.00)$ & $p=0.08$ \\
\hline VAS rest 1 & $2.55 \pm 1.76$ & 2.50 & $(0.00-5.00)$ & $0.50 \pm 0.78$ & 0.00 & $(0.00-2.00)$ & $1.20 \pm 1.73$ & 0.00 & $(-1.00-5.00)$ & $\mathrm{p}<0.001^{\star}$ \\
\hline VAS rest 2 & $0.75 \pm 1.20$ & 0.00 & $(0.00-4.00)$ & $-0.05 \pm 0.87$ & 0.00 & $(-2.00-2.00)$ & $0.40 \pm 1.53$ & 0.00 & $(-2.00-5.00)$ & $\mathrm{p}=0.12$ \\
\hline VAS night 1 & $2.35 \pm 2.53$ & 2.00 & $(0.00-7.00)$ & $1.61 \pm 2.19$ & 5.00 & $(0.00-7.00)$ & $2.25 \pm 1.91$ & 2.00 & $(0.00-7.00)$ & $\mathrm{p}=0.38$ \\
\hline VAS night 2 & $0.80 \pm 1.32$ & 0.00 & $(0.00-4.00)$ & $0.05 \pm 0.23$ & 0.00 & $(0.00-1.00)$ & $0.50 \pm 1.31$ & 0.00 & $(-2.00-4.00)$ & $\mathrm{p}=0.16$ \\
\hline
\end{tabular}

SD: Standard deviation; Min.: Minimum; Max. Maximum; VAS movement 1: difference between pre- and post-treatment values; VAS movement 2: difference between the values at the end of treatment and three months post-treatment; VAS rest 1: difference between pre- and post-treatment values; VAS rest 2: difference between the values at the end of treatment and three months post-treatment; VAS night 1: difference between the pre- and post-treatment values for night pain, VAS night 2: difference between the values for night pain at the end of treatment and three months post-treatment. KW: Kruskal-Wallis test, ${ }^{*}$ Bonferoni correction $\mathrm{p}<0.025$.

months later ( $\mathrm{p}=0.04, \mathrm{p}=0.03, \mathrm{p}<0.001$, respectively). The improvement observed after treatment and at the three-month follow-up was more remarkable in group U compared with group I. When the statistical differences between the three measurements in all groups were compared, greater improvement was found in the measurements at the three-month posttreatment in group $\mathrm{U}(\mathrm{p}=0.02)$.

Statistically significant improvement was found in group I at the end of treatment and at the three-month follow-up when the groups were compared regarding the results of the carpal compression test $(\mathrm{p}<0.001, \mathrm{p}<0.001)$.

Statistically significant improvement was seen in the two-point discrimination measurements in group I at the three-month post-treatment $(\mathrm{p}<0.001)$. When the statistical differences were compared between the three measurements in all groups, significantly greater efficacy was observed at the end of treatment and at the three-month follow-up in group I $(\mathrm{p}<0.001, \mathrm{p}<0.001$, (Bonferroni correction $0.05 / 3=0.0167$ ) (Table 3 ).

When the groups were compared in terms of the three measurements of the SWM examination [at the distal interphangeal (DIP) part of the second finger], statistically significant differences were observed after treatment and at the three-month follow-up, and this difference persisted in group I throughout the study and at the post-treatment three months later $(\mathrm{p}<0.001$, $\mathrm{p}<0.001)$. When the differences between monofilament measurements were compared, a statistically significant improvement was seen at the end of treatment and three months later in group I ( $\mathrm{p}<0.001, \mathrm{p}<0.001)$ (Bonferroni correction $0.05 / 3=0.0167$ ) (Table 4 ).

Table 3. Differences between the groups in three measurements of the two-point discrimination test

\begin{tabular}{|c|c|c|c|c|}
\hline & Group I & Group S & Group U & \\
\hline & $\overline{\text { Mean } \pm \text { SD }}$ & $\overline{\text { Mean } \pm \text { SD }}$ & $\overline{\text { Mean } \pm \text { SD }}$ & $\mathrm{KW} p^{*}$ \\
\hline After therapy, before therapy & $1.25 \pm 1.06$ & $0.00 \pm 1.13$ & $0.30 \pm 1.12$ & $\mathrm{p}<0.001^{\star}$ \\
\hline $\begin{array}{l}\text { Three-month follow-up-after } \\
\text { therapy }\end{array}$ & $0.75 \pm 0.91$ & $0.16 \pm 0.92$ & $0.40 \pm 1.09$ & $\mathrm{p}=0.14$ \\
\hline $\begin{array}{l}\text { Three-month follow-up-before } \\
\text { therapy }\end{array}$ & $2.00 \pm 1.33$ & $0.16 \pm 1.04$ & $0.70 \pm 1.03$ & $\mathrm{p}<0.001^{*}$ \\
\hline
\end{tabular}

\begin{tabular}{|c|c|c|c|c|}
\hline & Group I & Group S & Group U & \\
\hline & Mean \pm SD & Mean \pm SD & Mean \pm SD & $\mathrm{KW} p^{*}$ \\
\hline After therapy, before therapy & $0.44 \pm 0.44$ & $0.08 \pm 0.25$ & $0.15 \pm 0.31$ & $\mathrm{p}<0.001^{*}$ \\
\hline $\begin{array}{l}\text { Three-month follow-up-after } \\
\text { therapy }\end{array}$ & $0.15 \pm 0.32$ & $0.00 \pm 0.00$ & $0.05 \pm 0.18$ & $\mathrm{p}=0.12$ \\
\hline $\begin{array}{l}\text { Three-month follow-up-before } \\
\text { therapy }\end{array}$ & $0.60 \pm 0.39$ & $0.08 \pm 0.23$ & $0.20 \pm 0.33$ & $\mathrm{p}<0.001^{\star}$ \\
\hline
\end{tabular}




\begin{tabular}{|c|c|c|c|c|}
\hline & Group I & Group S & Group U & \\
\hline & Mean \pm SD & Mean \pm SD & Mean \pm SD & $p$ \\
\hline \multicolumn{5}{|c|}{ Health Assessment Questionnaire } \\
\hline Before therapy & $0.80 \pm 0.71$ & $0.77 \pm 0.73$ & $0.80 \pm 0.67$ & $\mathrm{p}=0.85$ \\
\hline After therapy & $0.42 \pm 0.56$ & $0.59 \pm 0.58$ & $0.66 \pm 0.61$ & $\mathrm{p}=0.24$ \\
\hline Three-month follow-up & $0.37 \pm 0.55$ & $0.46 \pm 0.55$ & $0.44 \pm 0.51$ & $\mathrm{p}=0.47$ \\
\hline \multicolumn{5}{|c|}{ Boston Symptom Severity Score } \\
\hline Before therapy & $26.40 \pm 8.78$ & $26.55 \pm 7.60$ & $30.55 \pm 8.84$ & $\mathrm{p}=0.22$ \\
\hline After therapy & $19.75 \pm 7.41$ & $23.55 \pm 10.10$ & $24.00 \pm 9.76$ & $\mathrm{p}=0.28$ \\
\hline Three-month follow-up & $17.70 \pm 5.61$ & $24.00 \pm 9.16$ & $22.90 \pm 9.74$ & $\mathrm{p}=0.05$ \\
\hline \multicolumn{5}{|c|}{ Boston Functional Status Score } \\
\hline Before therapy & $18.35 \pm 8.42$ & $16.38 \pm 7.01$ & $21.05 \pm 7.67$ & $\mathrm{p}=0.18$ \\
\hline After therapy & $14.35 \pm 4.81$ & $14.61 \pm 7.04$ & $17.55 \pm 7.66$ & $\mathrm{p}=0.24$ \\
\hline Three-month follow-up & $13.35 \pm 5.07$ & $15.00 \pm 6.76$ & $16.85 \pm 7.67$ & $\mathrm{p}=0.25$ \\
\hline
\end{tabular}

No statistically significant difference existed between the HAQ scores in the three groups before treatment $(\mathrm{p}>0.05)$. When comparing the statistical differences between the HAQ scores, improvements were seen in the groups, with statistically significant improvement in the group I three-month follow-up $(\mathrm{p}<0.02)$ (Table 5).

Statistically significant improvements were seen in the BQ-symptom severity in the groups at the threemonth post-treatment $(\mathrm{p}=0.05)$. When the statistical differences in the measurements of symptom severity were compared, statistically significant improvement was observed in the group I three-month follow-up $(p<0.001)$. When comparing the groups in terms of the BQ-functional capacity scores at the three time points, no statistically significant difference was seen ( $>>0.05)$. When the statistical differences in functional capacity measurements were compared, statistically significant improvement was observed in group I at the threemonth post-treatment $(\mathrm{p}=0.03)$ (Table 5).
Statistically significant differences existed only between the initial values of median nerve motor amplitudes when comparing the groups in terms of the EMG measurements (motor distal latency, motor amplitude, motor nerve conduction velocities and sensorial distal latency, sensorial amplitude and sensorial nerve conduction velocities of the median nerve) $(\mathrm{p}<0.01)$. In the post-treatment EMG measurements, a statistically significant difference was observed in motor and sensorial amplitudes of the median nerve $(p=0.02, p=0.04)$. There was no statistically significant difference between the groups in the EMG measurements at the three-month followup ( $p>0.05)$. When the differences between motor amplitude measurements of the median nerve were examined in all groups at the three different time points, statistically slightly greater improvement was seen in group $U$ three months after treatment $(p=0.04)$. Statistically significant improvements were seen in group I and, to a lesser degree, in group $U$

\begin{tabular}{|c|c|c|c|c|c|}
\hline & Group I & Group S & Group U & & \\
\hline & Mean \pm SD & Mean \pm SD & Mean \pm SD & $\mathrm{F}$ & $p$ \\
\hline \multicolumn{6}{|c|}{ Median nerve motor conduction (APB muscle) } \\
\hline MDL & $4.22 \pm 0.28$ & $4.25 \pm 0.34$ & $4.22 \pm 0.66$ & 0.90 & $\mathrm{p}=0.74$ \\
\hline MAmp & $14.82 \pm 4.19$ & $12.51 \pm 3.16$ & $12.27 \pm 3.80$ & 5.06 & $\mathrm{p}=0.01$ \\
\hline MSIH & $55.17 \pm 3.55$ & $53.51 \pm 3.30$ & $55.27 \pm 4.25$ & 1.05 & $\mathrm{p}=0.35$ \\
\hline \multicolumn{6}{|c|}{ Median nevre sensorial ( $2^{\text {nd }}$ finger) } \\
\hline DDL & $3.02 \pm 0.29$ & $3.06 \pm 0.26$ & $3.07 \pm 0.29$ & 0.06 & $\mathrm{p}=0.93$ \\
\hline DAmp & $55.38 \pm 17.10$ & $49.66 \pm 16.74$ & $48.51 \pm 20.10$ & 1.29 & $\mathrm{p}=0.17$ \\
\hline DSIH & $43.46 \pm 3.49$ & $43.43 \pm 4.56$ & $45.67 \pm 4.44$ & 0.21 & $\mathrm{p}=0.80$ \\
\hline
\end{tabular}

SD: Standard deviation; APB: Abductor Pollicis Brevis; MDL: Median nerve motor distal latency; MAmp: Median nerve motor amplitude; MSIH: Median motor nerve conduction velocity; DDL: Median nerve sensorial distal latency; DAmp: Median nerve sensorial amplitude; DSIH: Median sensorial nerve conduction velocity. 
when comparing all treatment groups regarding motor conduction velocities of the median nerve pre- and post-treatment and three months after treatment $(\mathrm{p}=0.04, \mathrm{p}=0.03)$. Statistically significantly greater improvement was seen in group $U$ when all treatment groups were compared in terms of median nerve sensorial amplitudes at the end of treatment and at the three-month follow-up $(\mathrm{p}<0.001)$ (Table 6).

\section{DISCUSSION}

This study examined the results of sham and dexamethasone iontophoresis along with ultrasound treatments in combination with splints, exercises, and ergonomic interventions in patients with CTS confirmed by clinical examination and electroneurography.

Carpal tunnel syndrome is one of the most frequently encountered disabling conditions in the community. Its initial treatment should be conservative, and several studies have been published on this topic. Some authors claim that nonsurgical methods are ineffective, but others say that patients with CTS can be treated successfully with conservative methods such as ultrasound, ergonomic intervention, exercises, or splints. ${ }^{[4-8,30]}$ Studies have noted that these physical agents may facilitate the recovery from CTS. ${ }^{[7,19-23]}$ We aimed to design treatment protocols for CTS and to compare iontophoresis, noted previously for its significant therapeutic effects, with ultrasound since the differences between them have been a topic of interest to investigators.

Some parameters of the present study confirm that protocol with dexamethasone iontophoresis is more effective than ultrasound treatment in CTS patients. The rate of improvement with iontophoresis was similar to that reported in other studies. ${ }^{[19-20]}$ However, Amirjani et al. ${ }^{[18]}$ observed that steroid iontophoresis was not more efficacious than the sham one, which may be due to the fact that iontophoresis was applied only six times during the trial. Their iontophoresis protocol was different from ours. Gurcay et al. ${ }^{[31]}$ demonstrated no superiority between splint-combined phonophoresis and iontophoresis in their study, but they suggested that phonophoresis with a splint would provide a better quality of life with regard to the patient's symptoms and better patient satisfaction. They did not use electroneurographic measurements, and the results were evaluated based on patient satisfaction. Gurcay et al. ${ }^{[32]}$ applied iontophoresis in another study, and they compared iontophoresis and steroid injection to carpal tunnel and reported that these conservative methods were effective.

Banta ${ }^{[20]}$ used iontophoresis and medical treatments in the management of CTS and found that $17 \%$ of the cases responded to wrist splinting plus nonsteroidal anti-inflammatory medications. Dexamethasone iontophoresis was found to be successful in 58\% of the cases at the six-month follow-up while medical treatment and iontophoresis failed in 35\%. These patients were referred for surgical treatment.

Some studies have reported the beneficial effects of ultrasound therapy. ${ }^{[7,23]}$ A portion of the clinical and electrophysiological outcomes (Phalen's test, Reverse Phalen's test, and median nerve sensorial amplitudes) were satisfactory in group U, but group I achieved greater improvements.

It has been shown in a study that workplace modifications or job changes are important in the treatment of CTS. ${ }^{[2]}$ In our study, ergonomic training for daily living activities was given to all patients. At the same time, we applied neutral position splinting as well as tendon and nerve gliding exercises and observed that these applications had supportive effects on the treatment, as has been similarly reported in the literature. We consider that the improvements in group I resulted from splinting, ergonomic measures, and exercises. A number of studies supporting this finding are available. ${ }^{[6,10,14,16,33]}$ Contrarily, it has been reported in a review that exercises were not beneficial in the management of CTS. ${ }^{[34]}$

Tendon and nerve gliding exercises have gained wide acceptance with the assumption that they relieve symptoms by stretching adhesions, increasing the distance between the median nerve and the transverse carpal ligament, and by reducing the compression and edema within the carpal tunnel. Their effects have been proven in several studies. ${ }^{[16]}$

It has been reported that the pressure was lowest when wearing a splint at night. ${ }^{[35]}$ Similarly, we also aimed to reduce the pressure in the carpal tunnel by applying neutral position splints. Other authors have also demonstrated the efficacy of splinting. ${ }^{[15,30]}$

In this study, we followed the patients at each session and until three months post-treatment and trained them to perform tendon and nerve gliding exercises. Based on oral feedback from our patients and statistical analyses, we observed that the exercises and treatment as a whole had symptom-relieving effects. 
Baysal et al. ${ }^{[36]}$ divided CTS patients into three groups and applied tendon and nerve gliding exercises + splinting to the first group, ultrasound + splinting to the second, and exercise + ultrasound + splinting to the third group. Although improvement was seen in all groups, it was most significant in the third group in which all three treatment modalities were used. In the present study, we applied exercise + splinting together with either ultrasound or iontophoresis and found that these combinations increased the treatment efficacy.

Ruksen et al. ${ }^{[37]}$ observed in their study that at the three-month follow-up, betamethasone injections and betamethasone phonophoresis combined with splinting and exercise were equally effective in the management of CTS.

In another study, iontophoresis and ultrasound treatments were applied in combination. Reduction in pain and numbness was seen in patients with mild to moderate CTS, but no improvement was found in patients with severe CTS. ${ }^{[8]}$ A few combination protocols have been published in the literature, and these should be evaluated in future studies.

It has been reported in a review that conventional therapies are successful in the treatment of CTS, but the number of long-term studies is insufficient. ${ }^{[1]}$ Generally, the follow-up period in those studies was eight weeks while it was 12 weeks in our study, and we found significant improvements with iontophoresis at follow-up.

In conclusion, when comparing the clinical and electrophysiological measurements performed pre- and post-treatment and at three months after treatment, we observed statistically significant improvement in some parameters (VAS score, pinch meter measurement, monofilament examination, two-point discrimination test, provocative tests, $\mathrm{APB}$ muscle test, $\mathrm{BQ}$, and median nerve motor conduction velocity) in group I at the end of treatment and at the three-month post-treatment. Improvement was observed in less parameters (Phalen's test, Reverse Phalen's test, and median nerve sensorial amplitudes) in group $U$, and it was usually seen at the end of treatment, but the duration of effect was not considered to be sufficient. In the groups receiving either iontophoresis or ultrasound treatment, improvement was seen in electrophysiological measurements, especially in motor nerve conduction velocity and sensorial amplitudes. Both active treatment modalities proved to be superior to the sham iontophoresis. One of the limitations of this study might be that group $\mathrm{S}$ received galvanic current combined with splint and tendon nerve gliding exercise, but since our aim was to evaluate the effect of dexamethasone iontophoresis, this group was accepted as sham.

The small number of subjects was another limitation of our study, but its design and methodology were superior to those of most previous studies. Moreover, our electroneurophysiology results were crucial for the study quality.

Iontophoresis and ultrasound have good efficacy in CTS management; however, combinations of these physical modalities should be evaluated to achieve better results.

Further clinical trials including large numbers of patients along with investigating the long-term effects of these methods are needed.

\section{Declaration of conflicting interests}

The authors declared no conflicts of interest with respect to the authorship and/or publication of this article.

\section{Funding}

The authors received no financial support for the research and/or authorship of this article.

\section{REFERENCES}

1. Cranford CS, Ho JY, Kalainov DM, Hartigan BJ. Carpal tunnel syndrome. J Am Acad Orthop Surg 2007;15:537-48.

2. Palmer KT, Harris EC, Coggon D. Carpal tunnel syndrome and its relation to occupation: a systematic literature review. Occup Med (Lond) 2007;57:57-66.

3. Bland JD. A neurophysiological grading scale for carpal tunnel syndrome. Muscle Nerve 2000;23:1280-3.

4. Dakowicz A, Latosiewicz R. The value of iontophoresis combined with ultrasound in patients with the carpal tunnel syndrome. Rocz Akad Med Bialymst 2005;50 Suppl 1:196-8.

5. Michlovitz SL. Conservative interventions for carpal tunnel syndrome. J Orthop Sports Phys Ther 2004;34:589-600.

6. Rozmaryn LM, Dovelle S, Rothman ER, Gorman K, Olvey KM, Bartko JJ. Nerve and tendon gliding exercises and the conservative management of carpal tunnel syndrome. J Hand Ther 1998;11:171-9.

7. Viera AJ. Management of carpal tunnel syndrome. Am Fam Physician 2003;68:265-72.

8. Hamamoto Filho PT, Leite FV, Ruiz T, Resende LA. A systematic review of anti-inflammatories for mild to moderate carpal tunnel syndrome. J Clin Neuromuscul Dis 2009;11:22-30.

9. Verdugo RJ, Salinas RA, Castillo JL, Cea JG. Surgical versus non-surgical treatment for carpal tunnel syndrome. Cochrane Database Syst Rev 2008;CD001552. 
10. Feuerstein M, Burrell LM, Miller VI, Lincoln A, Huang GD, Berger R. Clinical management of carpal tunnel syndrome: a 12-year review of outcomes. Am J Ind Med 1999;35:232-45.

11. Huisstede BM, Hoogvliet P, Randsdorp MS, Glerum S, van Middelkoop M, Koes BW. Carpal tunnel syndrome. Part I: effectiveness of nonsurgical treatments-a systematic review. Arch Phys Med Rehabil 2010;91:981-1004.

12. O'Connor D, Marshall S, Massy-Westropp N. Non-surgical treatment (other than steroid injection) for carpal tunnel syndrome. Cochrane Database Syst Rev 2003;CD003219.

13. Marshall S, Tardif G, Ashworth N. Local corticosteroid injection for carpal tunnel syndrome. Cochrane Database Syst Rev 2007;CD001554.

14. Papez BJ, Turk Z. Clinical versus electrodiagnostic effectiveness of splinting in the conservative treatment of carpal-tunnel syndrome. Wien Klin Wochenschr 2004;116 Suppl 2:24-7.

15. Werner RA, Franzblau A, Gell N. Randomized controlled trial of nocturnal splinting for active workers with symptoms of carpal tunnel syndrome. Arch Phys Med Rehabil 2005;86:1-7.

16. Pinar L, Enhos A, Ada S, Güngör N. Can we use nerve gliding exercises in women with carpal tunnel syndrome? Adv Ther 2005;22:467-75.

17. Anderson CR, Morris RL, Boeh SD, Panus PC, Sembrowich WL. Effects of iontophoresis current magnitude and duration on dexamethasone deposition and localized drug retention. Phys Ther 2003;83:161-70.

18. Amirjani N, Ashworth NL, Watt MJ, Gordon T, Chan KM. Corticosteroid iontophoresis to treat carpal tunnel syndrome: a double-blind randomized controlled trial. Muscle Nerve 2009;39:627-33.

19. Gökoğlu F, Fndkoğlu G, Yorgancoğlu ZR, Okumuş M, Ceceli E, Kocaoğlu S. Evaluation of iontophoresis and local corticosteroid injection in the treatment of carpal tunnel syndrome. Am J Phys Med Rehabil 2005;84:92-6.

20. Banta CA. A prospective, nonrandomized study of iontophoresis, wrist splinting, and antiinflammatory medication in the treatment of early-mild carpal tunnel syndrome. J Occup Med 1994;36:166-8.

21. Edel H, Bergmann P. Studies on the effect of ultrasonics in different dosage on the the neural-conduction velocity in man. Arch Phys Ther (Leipz) 1970;22:255-9. [Abstract]

22. Ebenbichler GR, Resch KL, Nicolakis P, Wiesinger GF, Uhl F, Ghanem AH, et al. Ultrasound treatment for treating the carpal tunnel syndrome: randomised "sham" controlled trial. BMJ 1998;316:731-5.

23. Piravej K, Boonhong J. Effect of ultrasound thermotherapy in mild to moderate carpal tunnel syndrome. J Med Assoc Thai 2004;87 Suppl 2:S100-6.

24. Bakhtiary AH, Rashidy-Pour A. Ultrasound and laser therapy in the treatment of carpal tunnel syndrome. Aust J Physiother 2004;50:147-51.
25. Oztas O, Turan B, Bora I, Karakaya MK. Ultrasound therapy effect in carpal tunnel syndrome. Arch Phys Med Rehabil 1998;79:1540-4.

26. Jackson DA, Clifford JC. Electrodiagnosis of mild carpal tunnel syndrome. Arch Phys Med Rehabil 1989;70:199-204.

27. Aygül R, Ulvi H, Karatay S, Deniz O, Varoglu AO. Determination of sensitive electrophysiologic parameters at follow-up of different steroid treatments of carpal tunnel syndrome. J Clin Neurophysiol 2005;22:222-30.

28. Sezgin M, Incel NA, Serhan S, Camdeviren $H$, As I, Erdoğan C. Assessment of symptom severity and functional status in patients with carpal tunnel syndrome: reliability and functionality of the Turkish version of the Boston Questionnaire. Disabil Rehabil 2006;28:1281-5.

29. Küçükdeveci AA, Sahin H, Ataman S, Griffiths B, Tennant A. Issues in cross-cultural validity: example from the adaptation, reliability, and validity testing of a Turkish version of the Stanford Health Assessment Questionnaire. Arthritis Rheum 2004;51:14-9.

30. Yagci I, Ucan H, Yilmaz L, Yagmurlu F, Keskin D, Bodur H. Comparison of splinting, splinting plus local steroid injection and surgery in carpal tunnel syndrome treatment. Turk J Phys Med Rehab 2006;52:55-60.

31. Gurcay E, Unlu E, Gurcay AG, Tuncay R, Cakci A. Assessment of phonophoresis and iontophoresis in the treatment of carpal tunnel syndrome: a randomized controlled trial. Rheumatol Int 2010. [Epub ahead of print]

32. Gurcay E, Unlu E, Bal A, Gurcay AG, Aydogdu E, Cakci A. Karpal tunel sendromunun tedavisinde iyontoforez, lokal kortikosteroid enjeksiyon ve non-steroid antiinflamatuar ilac etkinliğinin karşılaştırılması. Fırat Tıp Dergisi 2008;13:39-42.

33. Daniell WE, Fulton-Kehoe D, Chiou LA, Franklin GM. Work-related carpal tunnel syndrome in Washington State workers' compensation: temporal trends, clinical practices, and disability. Am J Ind Med 2005;48:259-69.

34. Piazzini DB, Aprile I, Ferrara PE, Bertolini C, Tonali $\mathrm{P}$, Maggi L, et al. A systematic review of conservative treatment of carpal tunnel syndrome. Clin Rehabil 2007;21:299-314.

35. Luchetti R, Schoenhuber R, Alfarano M, Deluca S, De Cicco G, Landi A. Serial overnight recordings of intracarpal canal pressure in carpal tunnel syndrome patients with and without wrist splinting. J Hand Surg Br 1994;19:35-7.

36. Baysal O, Altay Z, Ozcan C, Ertem K, Yologlu S, Kayhan A. Comparison of three conservative treatment protocols in carpal tunnel syndrome. Int J Clin Pract 2006;60:820-8.

37. Ruksen S, Oz B, Olmez N, Memis A. Comparison of clinical effectiveness of corticosteroid phonophoresis and local steroid injection treatment in carpal tunnel syndrome. Turk J Phys Med Rehab 2011;57:119-23. 